\title{
A virtual journey through school libraries and information centres (school media centres) in 61 countries in a digital Europe
}

\author{
Helen Boelens \\ Ph.D. research student \\ Middlesex University, London \\ United Kingdom
}

\begin{abstract}
Between 1997 and 2008, a successful educational matrix was developed at the Kalskeek College in Woerden, the Netherlands. A sub-matrix, known as the KILM (Kalsbeek Information Literacy Matrix) was also designed and implemented into the school library and information centre of the school. In 2003 the ENSIL community asked the researcher to find out whether or not the KILM could be implemented into other school libraries throughout Europe, using the available facilities. This paper presents part of the study which took place in 61 countries throughout Europe.
\end{abstract}

European school library survey; ENSIL, media and information literacy.

\section{Introduction}

The paper contains a summary of part of a research project which studied school libraries in 61 countries in Europe. It discusses the European section of a much larger Ph.D. research study which was carried out at local, national and European level.

The research at European level began in 2003, at the inaugural meeting of the ENSIL Foundation (ENSIL, 2003). Delegates expressed interest in a successful study which was taking place at the Kalsbeek College in Woerden, the Netherlands, a large comprehensive secondary school with approximately 2,500 pupils. This study, which commenced in 1997, was instigated by a member of the school leadership, Dr. Jaco Schouwenaar, who developed an educational matrix for use throughout the entire school. The writer of this paper developed a sub-matrix known as the Kalsbeek Information Literacy Matrix (KILM), which described the role of the school library and information centre as an integral part of the educational matrix. The aim of the educational matrix and the sub-matrix is to expedite the implementation of educational reforms, new forms of learning and the use of Information and Computer Technology (ICT) throughout the school in a constructive way. In the sub-matrix, special emphasis is placed on the use of information in both traditional and digital form and on the use of educational content. The final objective is an increase in educational quality and academic achievement. A description of the both the educational matrix and the submatrix (the KILM) can be found in the complete research document (Boelens, 2009).

During the ENSIL meeting, the writer agreed to enlarge the study, to see if it would be possible to implement the KILM into other school libraries in different countries throughout Europe, using the facilities which were currently available in those school libraries. A local study became a study at national and European level; the research has become the subject of a doctoral dissertation. 
The complete research document (Boelens, 2009) contains a glossary of terms which were used in this study. Before this European study could commence, certain terms needed to be defined at an international level. The following questions were asked:

\section{Question 1: How is Information and Computer Technology (ICT) defined in this study?}

'ICT is an expression embracing all the technologies that go to form the Information Society' (Allmedia, 2009).. At the Kalsbeek College, the use of ICT within the school is divided into three distinct categories: technical (hardware, installation, maintenance etc.), educational (including the use of content for educational purposes) and administrative (including communication).

Question 2: What is a school library and how can it be described at an international level?

During a review of the literature, publications were located which referred to "school libraries" as being part of the educational process, the library process, or both. These "school libraries" varied from a box of books in a cupboard somewhere in the school, to a will equipped library with professional staffing. This present study uses the description of a school library contained in the_IFLA / UNESCO School Library Manifesto (IFLA/UNESCO, 1999) and IFLA/UNESCO School Library Guidelines (IFLA/UNESCO, 2002).

Question 3: How can the concept of 'information literacy' or 'media literacy' be described at international level?

The review of the literature also showed that definitions of these concepts vary. This study uses a very simple definition of information literacy which has been recognised at international level: 'Information Literacy is the set of skills needed to find, retrieve, analyse, and use information’ (ACRL, 2000).

Media literacy is defined by the European Commission, Audiovisual and Media Policies (2008) as: 'the ability to access, analyse and evaluate the power of images, sounds and messages which we are now being confronted with on a daily basis and are an important part of our contemporary culture, as well as to communicate competently in media available on a personal basis. Media literacy relates to all media, including television and film, radio and recorded music, print media, the Internet and other new digital communication technologies. The aim of media literacy is to increase awareness of the many forms of media messages encountered in our everyday lives.'

Question 4: How can educational quality and academic achievement be described, and how can they be measured at international level?

Scheerens (2004) refers to the "Sixteen Quality Indicators" of educational quality, which were defined by the European Commission in 2000. Danielson (2002) confirms the importance of assessment at state level, country or national level and at international level. 
According to Fuchs \& Woßmann, (2004): 'the way in which an education system is organised can have a significant bearing on learning outcomes'. The UNESCO Education for All Global Monitoring Report 2009 : Overcoming inequality: why governance matters refers to educational quality, Chapter 2: Ensuring both equity and the quality of learning, describes in detail how educational achievement can be measured at an international or global level (UNESCO, 2009, chapter 2, p. 108).

\section{Question 5: Which European countries should take part in this study?}

ENSIL did not specify which countries should take part in this European study. When the research began, the intention was to carry out a survey of school libraries in countries which were members of the European Union and/or the Council of Europe. However, in 2008, after the publication of the IFLA/FAIFE World Report 2007 (IFLA/FAIFE, 2007), a decision was made to also include countries which had formerly been part of the U.S.S.R., since the report contained interesting information about school libraries in these countries. More information about this decision is provided later in this paper and also in the individual country reports ${ }^{1}$.

Table 1 below provides a list of the countries which have been included in this study. Individual language groups in Belgium are shown as separate countries. Also, England, Scotland, Wales and Northern Ireland are shown separately, even though they are part of the United Kingdom (see Boelens, 2009 for further clarification). 
$\underline{\text { Table } 1 .}$

\begin{tabular}{|c|c|c|c|c|c|}
\hline \multicolumn{6}{|c|}{ Selection of countries for this survey } \\
\hline & Country & EU Membership status & Council of Europe & Former USSR & \\
\hline 1 & Albania & & Council of Europe & & \\
\hline 2 & Andorra & & Council of Europe & & \\
\hline 3 & Armenia & & Council of Europe & & \\
\hline 4 & Austria & EU Member & Council of Europe & & \\
\hline 5 & Azerbaijan & & Council of Europe & & \\
\hline 6 & Belarus & & & Former USSR & \\
\hline 7 & Belgium & EU Member & Council of Europe & & \\
\hline 8 & Belgium (Dutch speaking) & & & & See Belgium \\
\hline 9 & Belgium (French speaking) & & & & See Belgium \\
\hline 10 & Belgium (German speaking) & & & & See Belgium \\
\hline 11 & Bosnia \& Herzegovina & & Council of Europe & & \\
\hline 12 & Bulgaria & EU Member & Council of Europe & & \\
\hline 13 & Croatia & Candidate EU Member & Council of Europe & & \\
\hline 14 & Cyprus & EU Member & Council of Europe & & \\
\hline 15 & Czech Republic & EU Member & Council of Europe & & \\
\hline 16 & Denmark & EU Member & Council of Europe & & \\
\hline 17 & Estonia & EU Member & Council of Europe & & \\
\hline 18 & Finland & EU Member & Council of Europe & & \\
\hline 19 & France & EU Member & Council of Europe & & \\
\hline 20 & Republic of Georgia & & Council of Europe & & \\
\hline 21 & Germany & EU Member & Council of Europe & & \\
\hline 22 & Greece & EU Member & Council of Europe & & \\
\hline 23 & Hungary & EU Member & Council of Europe & & \\
\hline 24 & Iceland & & Council of Europe & & \\
\hline 25 & Republic of Ireland & EU Member & Council of Europe & & \\
\hline 26 & Italy & EU Member & Council of Europe & & \\
\hline 27 & Kazakhstan & & & Former USSR & \\
\hline 28 & Kosovo & & & & \\
\hline 29 & Kyrgyzstan & & & Former USSR & \\
\hline 30 & Latvia & EU Member & Council of Europe & & \\
\hline 31 & Liechtenstein & & Council of Europe & & \\
\hline 32 & Lithuania & EU Member & Council of Europe & & \\
\hline 33 & Luxembourg & EU Member & Council of Europe & & \\
\hline 34 & Republic of Macedonia & Candidate EU Member & Council of Europe & & \\
\hline 35 & Malta & EU Member & Council of Europe & & \\
\hline 36 & Moldavia & & Council of Europe & & \\
\hline 37 & Monaco & & Council of Europe & & \\
\hline 38 & Montenegro & & Council of Europe & & \\
\hline 39 & Netherlands & EU Member & Council of Europe & & \\
\hline 40 & Norway & & Council of Europe & & \\
\hline 41 & Poland & EU Member & Council of Europe & & \\
\hline 42 & Portugal & EU Member & Council of Europe & & \\
\hline 43 & Romania & EU Member & Council of Europe & & \\
\hline 44 & Russian Federation & & Council of Europe & & \\
\hline 45 & San Marino & & Council of Europe & & \\
\hline 46 & Serbia & & Council of Europe & & \\
\hline 47 & Slovakia & EU Member & Council of Europe & & \\
\hline 48 & Slovenia & EU Member & Council of Europe & & \\
\hline 49 & Spain & EU Member & Council of Europe & & \\
\hline 50 & Sweden & EU Member & Council of Europe & & \\
\hline 51 & Switzerland & & Council of Europe & & \\
\hline 52 & Tajikistan & & & Former USSR & \\
\hline 53 & Turkey & Candidate EU Member & Council of Europe & & \\
\hline 54 & Turkmenistan & & & Former USSR & \\
\hline 55 & Ukraine & & Council of Europe & & \\
\hline 56 & U.K. (United Kingdom) & EU Member & Council of Europe & & \\
\hline 57 & U.K. (England) & & & & See U.K. \\
\hline 58 & U.K. (Northern Ireland) & & & & See U.K. \\
\hline 59 & U.K. (Scotland) & & & & See U.K. \\
\hline 60 & U.K. (Wales) & & & & See U.K. \\
\hline 61 & Uzbekistan & & & Former USSR & \\
\hline
\end{tabular}




\section{Question 6: What is the importance of language in this study?}

Language is very important within Europe, for reasons related to national pride or identity. It resulted in certain limitation during this study. In the countries which appear in Table 1, there is a total of 52 official national languages (see Table 2), 23 of which are official languages of the European Union. In general, the EU uses English, French and German as procedural languages (European Commission, Multilingualism, 2009). In this present study, research was carried out in English and Dutch, and to a limited extent in French and German.

Table 2.

\begin{tabular}{|c|c|}
\hline \multicolumn{2}{|c|}{ List of languages which are taken into account in this study } \\
\hline 1 Abkhazian & \begin{tabular}{l|l}
27 & Italian (italiano) \\
\end{tabular} \\
\hline 2 Albanian (Shqip, Tosk (Toskë) is the official dialect) & $28 \mid$ Kazakh \\
\hline 3)Armenian & $29 \mid$ Kyrgyz \\
\hline 4 Azerbeidzjanian & 3 Latvian (latviesu valoda) \\
\hline 5 Azeri & 31|Lithuanian \\
\hline 6 Basque & 32 Luxembourgish,French, German \\
\hline 7 Belarusian & 33 Macedonian $68 \%$, Albanian $25 \%$ \\
\hline $8 \mid$ Bosnian & 34|Maltese (Malti) \\
\hline $9 \mid$ Bulgarian & $35 \mid$ Moldovan (virtually same as Romanian language), \\
\hline 10|Catalan & 36 Norwegian (nynorsk and bokmal) \\
\hline 11 Croatian (hrvatski) & 37 Polish (polski) \\
\hline 12 Czech (cestina) & 38|Portuguese (português) \\
\hline 13 Danish (dansk) & $39 \mid$ Romanian (romana) \\
\hline 14 Dutch (Nederlands)/Flemish & $\begin{array}{ll}40 & \text { Romansch }\end{array}$ \\
\hline $15 \mid$ English & $41 \mid$ Russian \\
\hline 16|Estonian (eesti keel) & 42 Serbian \\
\hline $17 \mid$ Finnish (suomi) & 43 Serbo-Croatian (ljekavian dialect - official) \\
\hline 18|French (français) & 44 Slovak (slovensky jazyk) \\
\hline 19 Frisian & 45 Slovenian (slovenski jezik) \\
\hline 20 Galician & 46 Spanish (Castilian) \\
\hline 21 Georgian, & 47) Swedish (svenska) \\
\hline 22 German (Deutsch) & 48|Tajik \\
\hline 23 Greek (elliniká, the Koine-Demotic version) & $49 \mid$ Turkish (türkçe) \\
\hline $24 \mid$ Hungarian (magyar) & 50|Turkmen \\
\hline 25 Icelandic & 51|Ukrainian \\
\hline 26 Irish (Gaeilge), & 52 Uzbek \\
\hline
\end{tabular}




\section{Historical background information}

An information search was carried out for historical_background information about school libraries in Europe. Gates (1968) explains how the school library developed up until 1960 'since a look at its history may shed some light on why it has grown as it has and why its current status is what it is'. He states:

'The purpose of school libraries has always been to support instruction in the school; this ignores the fact that school libraries were often established for other purposes unrelated to school instruction, as, for instance, meeting the recreational reading needs of the children, or the needs of adult members of the community'.

In particular, information provided by Dr. Anne Clyde’s comprehensive history of school librarianship (in some English speaking countries including the United Kingdom) was of interest (Clyde, 1981). Clyde states:

'While the school library is a widely occurring institution which most people readily identify and understand, its history tends to be treated in the literature as a subsidiary part of the history of the public or children's library, or as minor aspect of educational history.'

In this paper, the writer questions whether or not the school library (throughout Europe) is, in actual fact, readily identified and understood by participants in the educational process and in the library process. Do they all have a similar vision of what a school library actually is?

Clyde also discusses the development of schools of librarianship in Great Britain, in the period to 1945. 'One area in which a new need was identified was trained manpower in the school library. ... (however) there was a great deal of ambivalence on this in the standards themselves. Even today (in 1981) ... (at international level) there is still considerable disagreement about what education and training is seen as desirable for such people (school librarians or teacher librarians), and considerable variation in the educational backgrounds of people employed in such positions. ...Three types of school librarians emerged in the United States and in Great Britain, ... all three gaining some degree of acceptance:

- the teacher librarian who had undertaken a full course in teacher training plus a full professional course in librarianship or school librarianship;

- the librarian who brought professional library qualifications to the work of the school library;

- the teacher in charge of the library, part- or full-time, often with a considerable teaching load, and usually with only a short course completed (anything from a week to a semester) in school library organisation. ...

- Many people in charge of school libraries throughout the twentieth century had no library qualifications at all.'

Information about the present day training of school librarians is contained in each individual country report (Boelens, 2009).

According to Clyde (1981): 
'In Great Britain and the United States, in the twentieth century, library services to schools were provided by Public Libraries. These services varied from the mere provision of juvenile collections, to the encouragement of library visits by classes from local schools, and usually some library instruction to those classes, the provision of special collections for teachers, the provision of a reference and loan collection within the school itself for the use of pupils and teachers'.

Clyde also states that school libraries in primary schools were developed for a variety of reasons, including the provision of recreational materials, the encouragement of reading to develop "the reading habit" in children, and the provision of reference books and curriculum-related materials. She also makes the following important statement:

'It is possible that little attention has been paid to the school library in historical studies because it has traditionally been seen as playing a dependent role in both education and librarianship. Its budget, for instance, usually forms only a small part of that of the school or of the public library authority, and its staff, when provided at all, has generally been less well qualified than either the school teaching staff or the public library staff, until well into the $20^{\text {th }}$ century.' (Clyde, 1981).

From a European perspective, Clyde's study provides information about the historical background of school libraries in the United Kingdom, however it has been difficult to locate historical information about school libraries in other parts of Europe, especially in those countries where English is not the national or official language. Any other historical information about school libraries in the 61 countries in this study has been placed in the individual country reports in the complete research document (Boelens, 2009).

\section{"Silent" School libraries which came under Communist influence after World War 2 or were part of the former U.S.S.R..}

As mentioned in Question 5 above, the IFLA/FAIFE World Report 2007 (IFLA/FAIFE, 2007) contains information about school libraries which had, up until that time, been "silent"- in other words, very little was known about these school libraries in other parts of Europe. In 2007, however, reports of large numbers of school libraries were sent to the IFLA by National Libraries and other library organisations (see Table 3 below). 
$\underline{\text { Table } 3}$

\begin{tabular}{|c|c|c|}
\hline \multicolumn{3}{|c|}{ Countries in former USSR and under Communist influence after World War 2.} \\
\hline \multicolumn{3}{|c|}{ Estimate - Nr. school libraries reported in IFLA/FAIFE World Report 2007.} \\
\hline 1 & Albania & 1700 \\
\hline 2 & Armenia * & 1353 \\
\hline 3 & Azerbaijan * & No information provided \\
\hline 4 & Belarus * & No information provided \\
\hline 5 & Bosnia \& Herzegovina & 204 \\
\hline \multirow[t]{2}{*}{6} & Bulgaria (estimate Nr. 1) & 1465 \\
\hline & Bulgaria (estimate Nr. 2) & 2599 \\
\hline 7 & Croatia & 1264 \\
\hline 8 & Czech Republic (Czechoslovakia) & 4151 \\
\hline 9 & Estonia * & 451 \\
\hline 10 & Republic of Georgia * & No information provided \\
\hline 11 & Germany (East Germany DDR) & See country report Germany \\
\hline 12 & Hungary & 4347 \\
\hline 13 & Kazakhstan * & 6852 \\
\hline 14 & Kyrgyzstan * & 2133 \\
\hline 15 & Latvia * & 1099 \\
\hline 16 & Lithuania * & 1312 \\
\hline 17 & Rep. of Macedonia & No information provided \\
\hline 18 & Moldova * & 1433 \\
\hline 19 & Poland & 15200 \\
\hline 20 & Romania & No information provided \\
\hline 21 & Russia * & 66000 \\
\hline 22 & Serbia & 1700 \\
\hline 23 & Slovakia & 5483 \\
\hline 24 & Slovenia & 648 \\
\hline 25 & Tajikistan * & No information provided \\
\hline 26 & Turkmenistan * & No information provided \\
\hline 27 & Ukraine * & 20600 \\
\hline 28 & Uzbekistan * & No information provided \\
\hline & * Member of former U.S.S.R. & \\
\hline
\end{tabular}

In 2007, some countries on the list had joined the European Union and had already provided information to this research; others had not. This new information (IFLA/FAIFE, 2007) inspired the researcher to dig deeper, to find out more about these "silent" school libraries. Did communist regimes place importance on school libraries? The following questions were asked: 
- How can these school libraries be described?

- How can they be compared with school libraries in other countries in this study?

- What kind of facilities do they have?

- When were they set up?

- Did the conditions in these libraries comply with the conditions described in the IFLA School Library Manifesto?

- What happened to these school libraries after countries achieved independence from the U.S.S.R or when Communist influenced ceased?

Some "silent" libraries came under Communist influence after World War 2; others were part of the former U.S.S.R.. A review of the literature shows that, during that time, important things happened in the school libraries, and for this reason all the countries shown in Table 3 are included in this research, (even though some of them are actually located in Central Asia). When this was relevant to the present study, the researcher contacted each institution which provided information to the IFLA/FAIFE World Report 2007 and requested more information about school libraries.

Long before the Russian Revolution in 1917, Lenin had been thinking and writing about the need to harness libraries in the struggle for mass education and political awareness (Francis, 1971). This book provides statistical information about the increase in the number of libraries from 1914 - 1965, including the great increase in the number of school libraries (especially at secondary and technical schools). He describes the goals which were set for libraries in general and also for school libraries, and provides statistics about the growth of (school) libraries, per country in the U.S.S.R. Clear statistics about the (traditional) collection, available facilities and library staff (including their education) in all the U.S.S.R. republics are provided. $90 \%$ of all library workers had received higher (tertiary) or secondary education; in the 1965/66 school year, 50,000 people obtained higher (tertiary) and secondary library training. According to Francis: 'the higher (tertiary) educational establishments and technical schools annually send out 10 thousand specialists in library science'.

Clearly, the U.S.S.R. and the countries which had come under communist influence placed importance on their school libraries because they valued education and wanted literate citizens. Emphasis was placed on literacy, especially in the Russian language, since literacy was used as a means of communist indoctrination. In 1917, the population in some of the countries in the U.S.S.R. was nearly $100 \%$ illiterate. Statistics on adult literacy from 2007 show that most of these countries have now attained nearly $100 \%$ adult literacy. By establishing school libraries, and by sending suitable Russian books from Moscow, children and young people had access to books to read. School libraries were usually run by teacher librarians who were trained at university level and who had a clear place in the school system (Ganitskaya \& Frolova, 1978).

Since the dissolution of the U.S.S.R., many of these libraries encountered dire financial problems. They did not have sufficient funding and no longer received books from Moscow. Interviews confirm that new national governments now want people to read in their own national language (and not in the Russian language). In some countries, very little (children's) literature is available in these languages. The research also reveals that many of these countries are still proud of their school libraries. Step by step, attempts are being made to renovate them and bring them up to standards contained in the IFLA/UNESCO School Library Manifesto (IFLA/UNESCO, 1999). Certain countries have received international aid in order to do this. In some of these countries, (school) librarians are still being trained at a high level (Boelens, 2009). 
However, on a negative note, during informal, some school librarians were referred to quite openly as: 'clerks who have been relegated to the "storage rooms" called libraries'. This comment refers to the fact that school librarians are also responsible for the distribution of textbooks in some of the countries. Unfortunately not much information has been received about the introduction of ICT into school libraries in many of these countries. This could be a subject for further study.

Sometimes, information for this study was provided by people who live in remote places and are unfamiliar with western (school) library and educational processes. However, once contact had actually been made, they went to a great deal of time and trouble to provide information (in English) for this study. Although these school libraries may not have extensive ICT facilities which in turn provide digital library facilities, they were set up to provide a certain quality in education. The evidence reveals that they continue to try to do so (within certain limits). This is confirmed in some countries by international testing.

\section{International school library surveys.}

Three other international library surveys (which included school libraries) were located and studied, in order to make comparisons with the present study.

The Singh study. In 1993, Dr. Diljit Singh published his doctoral dissertation, which was a worldwide survey of primary and secondary school libraries (Singh, 1993). This publication contained (quantitative) information about school libraries in 23 European countries. Singh approached Missions to the United Nations, asking them to appoint an expert to complete the survey for each country. Although there was good co-operation on this survey, it is unclear whether the interviewees were library or educational experts. Also, it is possible that some "school libraries" which were included in Singh's study may not comply with definitions used for this present research. When Singh's study was carried out, the important IFLA/UNESCO documents: the IFLA/UNESCO School Library Manifesto (IFLA/UNESCO, 1999) and the IFLA/UNESCO School Library Guidelines (IFLA/UNESCO, 2002), which clarify the role of the school library and give important support to school librarianship throughout the world, had not yet been published. The true implications of the introduction of ICT into the school, and into the school library, were also not yet evident.

The Libecon millennium study. In 2000, LibEcon published a millennium study of Library Economics in Europe (Libecon, 2000). Chapter 8 of this particular study was concerned with school libraries. 31 countries in Europe took part. Once again, no clear definition was provided for a school library. This means that, in some cases, the kind of "school libraries" which may not comply with definitions used by this present research, were included in the statistics. Contact with the LibEcon researchers has confirmed that there was a lack of reliable information about school libraries at national level.

The UNESCO pilot study, 2008. In 2008 a pilot survey of academic and public libraries was carried out by UNESCO (UNESCO, Institute of statistics, 2008). UNESCO was contacted and was asked why school libraries had not been included in the study. UNESCO replied that there are severe worldwide problems in obtaining accurate, quality data on (school) 
libraries at national level. They had hoped that the pilot survey would reveal an improvement in this area, but unfortunately, this was not the case. UNESCO also raised questions about the kind of data which would be collected during an international study of school libraries - should this be quantitative data about the size of collection etc. or qualitative data.

The UNESCO project leader, Mr. Simon Ellis, was informed by the writer that a number of national school library associations (in Europe) are now holding national surveys and that, in some countries, new statistics (both quantitative and qualitative) are becoming available on school libraries at national level. She also reiterated the importance of the inclusion of school libraries in international library surveys. Ellis replied that UNESCO collects data which is likely to be available for the majority of countries in the world. If there were national studies from the majority of countries, above all in Africa and South-east Asia - the areas which are of greatest priority for UNESCO - then this organisation would reconsider the possible inclusion of school libraries in its surveys.

UNESCO confirms some of the problems which have been encountered by the writer in gathering data for the present research (see below). However, many national (school) library associations now have the facilities to carry out national surveys using ICT and free software. Suggestions are available about which could be used throughout the world in national school library surveys. The collected information could be used for school library advocacy at national and international level.

\section{School library tradition in Europe.}

In many cases, European countries which did not return information to the Libecon survey also failed to return the IFLA/FAIFE World Report 2007 or the ENSIL surveys. This confirms that information on school libraries was unavailable and that some countries within Europe do not have a school library tradition.

\section{Research theory}

The theory behind this study at European level is as follows: If schools throughout Europe are able to provide conditions similar to those which exist in the school library and information centre at the Kalsbeek College, they should be able to implement the KILM (Kalsbeek Information Literacy Matrix). Throughout this research, the School Library and Information Centre (SLIC) at the Kalsbeek College is used as the standard, for example: the quantity and quality of both the traditional and the digital collection, facilities for teachers and pupils, training of library staff, budget, opening hours etc.. A description of these facilities and also both the educational matrix and the KILM can be found in the complete research document (Boelens, 2009).

\section{Research questions:}

The research will attempt to examine conditions which exist in school libraries throughout Europe. By examining conditions which are essential for the application of the KILM, the study will try to ascertain which school libraries and information centres would be 
able to (partially) implement the sub-matrix, or a similar kind of tool, using the facilities which they have at their disposal.

\section{Initial research}

\section{ENSIL survey, 2004.}

The first ENSIL questionnaire, prepared in 2004, took the form of a traditional (international) library survey. Questions were asked about the facilities which were available in school libraries so that a comparison could be made against the standard (which is the SLIC at the Kalsbeek College). Only 6 questionnaires were returned. An attempt was made to gain insight into the reasons for this poor response and for the poor quality of information contained in some of the actual responses. Below is a summary of the reasons which were given:

Addresses. Questionnaires were sometimes sent to addresses (including E-mail addresses) which were no longer valid (see Boelens, 2009).

Language. The survey was sent out in English and not in other European languages.

Definitions. Answers needed to be based on the same definitions and not on peoples' opinions.

Differences in school systems. School systems vary throughout Europe (Eurydice, 2007). The questionnaire did not allow for these differences.

Accurate information was unavailable since there had not been a recent national survey of school libraries.

Authority. Some recipients (including national school library associations) were not authorised to complete the survey.

Politics. Some answers had political connotations - interviewees were worried about political repercussions.

\section{ENSIL Survey, 2005.}

Due to the poor response to the first survey, a registered letter and/or an E-mail message was sent to the directors of National Libraries in 52 countries, asking for information about:

- Availability of school libraries in each country; school library tradition

- Availability of trained school librarians; education and training of school librarians;

- Accurate addresses of national (school) library associations.

Fifteen National Libraries returned this questionnaire. When compared with data received from national (school) library associations or from Ministries of Education or other educational authorities, it was clear that there are discrepancies in the information which is provided. Once again, definitions, in particular the definition of a "school library", played a role 
in the quality of information which was received. The language of the survey, English, did not seem to be a problem for the National Libraries.

At this point in the research, and due to poor response to the two ENSIL surveys, and the lack of quality information which was received, the researcher tried to find out which conditions are "imperative" within the school library and information centre in order to implement the KILM. As a result, during 2007 and 2008, other short ENSIL questionnaires were sent out, asking specific questions relating to these imperative conditions. An E-mail was also sent to universities which claimed to have a programme at university level for the training of school librarians (using 3 international lists), asking questions about these courses. All the information which has been received as a result of these additional questionnaires and E-mails has been recorded in the individual country reports (Boelens, 2009).

\section{A report on each country in this survey}

The researcher decided to write an individual report on each of the 61 countries which are part of this survey, using a paradigmatic model. Each country report contains information which had been retrieved from the earlier ENSIL surveys and questionnaires, from recently published documents and publications, from renewed (international) databases, via E-mail and Web 2.0 communication and has its own set of references. These reports are contained in a detailed appendix in the complete research document. (Boelens, 2009). Using these individual country reports, it became possible to compare the situation in school libraries in different countries and to analyse the data. Conclusions could then be reached. The country reports were made for the purpose of comparison. In no way are they intended as criticism of conditions in school libraries or of decisions which have been made regarding school libraries in different countries.

The paradigmatic model asks questions (per country) about:

- Population, Gross National Income per capita (GNI) and Purchasing Power Parity (PPP);

- Education at primary and secondary school level, including national expenditure on education, adult literacy, school enrolment ratios, training of teachers, compulsory education and gross enrolment rates;

- Ranking in international tests which relate to educational achievement;

- The introduction and use of ICT in schools (including the school library);

- ICT policy in schools;

- Media literacy and information literacy policies;

- Libraries, including school libraries and information centres;

- General background information;

- General background information about schools and education;

- Specific information about school libraries and information centres.

Some questions in the paradigmatic model could not be answered for each of the individual countries in the survey - in this case, the word 'unknown' appears in the table. A final table, which summarised the available information from each country, was then prepared and was used in comparisons between the 61 countries in this survey. A total of 191,730 school libraries have been reported to this study from different sources (Table 4, below). Some 
information is conflicting, depending on the source (an educational authority or a library authority).. Other information is incomplete

The parameters described in the paradigmatic model have been used to determine whether or not school libraries meet the criteria which were originally set by the Kalsbeek College for the implementation of the KILM. Because of the impact of new forms of learning and ICT on the school itself, and also the changes within ICT which occur at an alarming rate, these criteria are continuously changing, not only at the Kalsbeek College but also in each of the 61 countries which have been included in this study. 
Table 4.

Number of school libraries reported to this study by different sources (see Appendix III, per country) and the percentage of schools with computers in the school libraries.

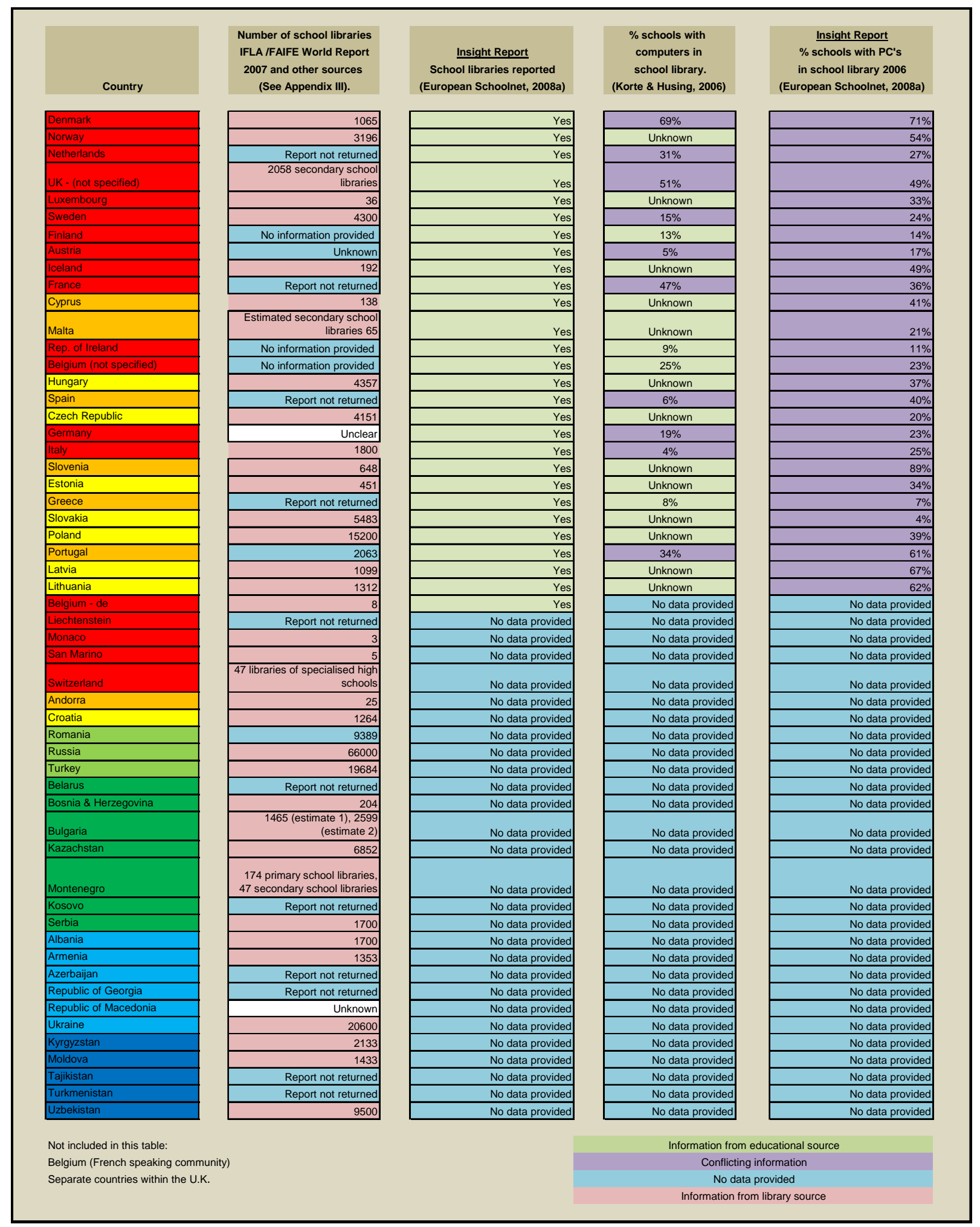

Explanation of colour coding in column 1:

\begin{tabular}{|l|c|c|c|c|c|c|}
\hline 1 & 2 & 3 & 4 & 5 & 6 & 7 \\
\hline \multicolumn{6}{|c|}{ GNI ranking in Europe $: 1$ = wealthiest, 7 = poorest. } \\
\hline
\end{tabular}




\section{Conclusions}

Since its inception in 1997, the KILM has become a symbol for the integration of educational reforms, new forms of learning and ICT throughout the entire school, in order to enhance educational quality, placing specific emphasis on the use of the school library and information centre. In some of the countries in this survey, reliable data on school libraries is unavailable, or available in very limited amounts. This made a comparison of available facilities difficult.

The original research question from ENSIL was: 'Is it possible to implement the learning sub-matrix known as the KILM into other school libraries in Europe, using the available facilities?'. In order to carry out this study, a set of nine research questions were formulated. These research questions, together with answers which have been found, appear below in Table 5.

Table 5

\begin{tabular}{|c|c|c|}
\hline \multicolumn{3}{|c|}{ Answers to the research questions } \\
\hline & Research questions & Answers \\
\hline 1. & $\begin{array}{l}\text { What is the present state of school libraries } \\
\text { at European level? What is their mission }\end{array}$ & $\begin{array}{l}\text { Since many of the countries in this survey do not use a specific } \\
\text { definition for what a school library actually is, there is no specific way } \\
\text { in which this question can be answered. Some countries have } \\
\text { excellent school libraries run by trained personnel. Others are } \\
\text { merely a box of books in a school cupboard. The mission of the } \\
\text { school library has not been clearly defined in many countries. }\end{array}$ \\
\hline 2. & What are their goals in a digital Europe? & $\begin{array}{l}\text { The IFLA/UNESCO Manifesto (IFLA/UNESCO 2006) and the } \\
\text { IASL/UNESCO School Library Guidelines (IFLA/UNESCO 1999) } \\
\text { define these goals according to the library process and are } \\
\text { translated into a number of languages which are relevant to this } \\
\text { survey. Clear definitions and goals for the "school library", as } \\
\text { defined by the educational process, per country, were difficult to } \\
\text { locate. }\end{array}$ \\
\hline 3. & $\begin{array}{l}\text { What is the role of school libraries and the } \\
\text { library staff within the school since the } \\
\text { introduction of education reforms, new forms } \\
\text { of learning and ICT into schools? }\end{array}$ & $\begin{array}{l}\text { This role varies from country to country, as described in the country } \\
\text { reports. In poorer countries, the school library is are often important, } \\
\text { however its role is related to literacy goals and the distribution of } \\
\text { books and textbooks. In wealthier countries, the school library and } \\
\text { the library staff play an important role in the implementation of ICT } \\
\text { and new forms of learning in an interdisciplinary way throughout the } \\
\text { school. }\end{array}$ \\
\hline 4. & $\begin{array}{l}\text { Is it possible to evaluate the effect which } \\
\text { these school libraries have on educational } \\
\text { quality, learning outcomes and academic } \\
\text { achievement, at European level? }\end{array}$ & $\begin{array}{l}\text { This would need to be the subject of a further, very specific study, at } \\
\text { European level which would measure the effect on an international } \\
\text { level. The researcher is presently working with other researchers, on } \\
\text { an international assessment tool. }\end{array}$ \\
\hline 5. & What are the critical success factors? & $\begin{array}{l}\text { These are described in the conclusions to Chapter } 4 \text { in the complete } \\
\text { research document. However the most important critical factor is the } \\
\text { vision of the school leadership and its ability to implement change } \\
\text { management throughout the entire school. Without this, the KILM } \\
\text { cannot be implemented. }\end{array}$ \\
\hline 6. & $\begin{array}{l}\text { Would it be possible to introduce the sub- } \\
\text { matrix known as the KILM into (some of) } \\
\text { these school libraries? }\end{array}$ & $\begin{array}{c}\text { This would be primarily dependent upon the educational vision and } \\
\text { leadership qualities of the school leadership. It would then be } \\
\text { dependent upon the quality of the library staff and the facilities } \\
\text { which are available within the school and the school library. } \\
\text { Reference to the country reports shows which countries have } \\
\text { adequate facilities and trained staff. }\end{array}$ \\
\hline 7. & $\begin{array}{l}\text { What facilities would be needed for a } \\
\text { successful implementation? }\end{array}$ & $\begin{array}{l}\text { These facilities may vary - the ability of the school library staff to } \\
\text { adjust to different facilities is the most important factor. }\end{array}$ \\
\hline 8. & $\begin{array}{l}\text { Are there other factors which are important in } \\
\text { order to implement the KILM throughout the } \\
\text { school? }\end{array}$ & The co-operation between different members of the school staff. \\
\hline 9. & $\begin{array}{l}\text { What changes in educational quality, } \\
\text { learning outcomes and educational } \\
\text { achievement could be expected? }\end{array}$ & $\begin{array}{l}\text { An increase in educational quality, learning outcomes and academic } \\
\text { achievement }\end{array}$ \\
\hline
\end{tabular}


A review of the individual country reports shows that a limited number of countries in Europe are reaching similar conclusions to those expressed in the KILM, and also have the facilities in their school libraries to implement a similar matrix.

After a detailed study had been completed, it became apparent that other important conclusions had also been reached:

- The quality of education, at European level is limited, per country, by various factors such as poverty, wars and disasters, politics, educational policy and the quality of the education system, investment in education, the academic quality of the teaching staff, the facilities which the school provides and the attitudes of the school community, including pupils and parents.

- The quality of the school library is only partially dependent upon the facilities or the amount of ICT hardware or software which it has at its disposal. These facilities need to be in balance with the educational objectives of the school (Kennisnet, 2006). These factors are co-ordinated by the school leadership.

- Countries which have made large investments in education and also in ICT hardware and software have not necessarily shown an increase in educational quality and academic achievement.

- School libraries are special libraries which play an important role in two different processes - the educational process and the library process. Co-operation between these two processes is essential if school libraries are to be effective. School libraries no longer play a dependent role in education and librarianship (Clyde, 1981).

- Since the introduction of ICT within the school, the trained school librarian plays an even more important and essential additional role - that of a school information specialist.

- The national school library law in each country is very important. It provides clear definitions of a "school library" and also describes the work of the school library; it provides "status" for the school library and reduces confusion which may result in inaccurate data being forwarded to national or international surveys.

- Accurate, quality data on school libraries needs to be collected at national level, on a worldwide basis.

- Some countries within Europe do not have a school library tradition.

- All libraries should support each other's work. There should not be a competition for status or funding.

Other important factors, which have been studied in earlier research, were confirmed:

- Under certain specific circumstances and when there is co-operation within the school community, school libraries enhance academic achievement.

- The school librarian is qualified as both a teacher and a librarian. This person teaches/ instructs pupils and teachers throughout the school, and has similar status to other teachers.

- The training and re-training of school librarians is imperative and must occur frequently, in order to keep abreast of new ICT trends. The research shows that training at tertiary level no longer takes place in a number of countries, for various reasons.

- School leaders and other teachers sometimes do not understand the work which the school librarian carries out. They do not realise the many advantages of co-operation with the school librarian. 
The ENSIL foundation has prepared a folder in 12 European languages which will be distributed during the IASL 2009 conference. It will also be made available via the ENSIL website (www.ensil.eu). Its purpose is to provide information and tips for the promotion of school librarianship throughout Europe.

The writer wishes to thank all those people who co-operated with her during this study.

\section{References}

ACRL (Association of College \& Research Libraries), (2000). Information Literacy Competency Standards for Higher Education . Chicago, Illinois : ACRL http://www.ala.org/ala/mgrps/divs/acrl/standards/informationliteracycompetency.cfm Accessed on 8 February 2009.

ALLMEDIA (Alliance for a Media Literate Europe), (2009). eLearning Dictionary. http://lampan.sag.karlstad.se/ allmedia/index.php?page=http://lampan.sag.karlstad.se/ allmedia/diction ary.php Accessed on 6 February 2009.

BOELENS, H. (2009). The evolving role of the school library and information centre in a digital Europe. Dissertation submitted for the degree of Doctor of Philosophy in the School of Arts and Education (not yet published as of 20 May 2009). London : Middlesex University.

CLYDE, L. (1981). The Magic Casements: A survey of school library history from the eight to the twentieth century. Thesis submitted for the degree of Doctor of Philosophy in the Department of History. Townsville, QLD. : James Cook University.

DANIELSON, C. (2002). Enhancing Student Achievement: A Framework for School Improvement. Alexandria, VA : Association for Supervision and Curriculum Development.

ENSIL Foundation (European Network for School Libraries and Information Literacy). (2003). About ENSIL. www.ensil.eu Accessed on 19 May 2009.

EUROPEAN COMMISSION, Audiovisual and Media Policies (2007). Study on the Current Trends and Approaches to Media Literacy in Europe, Final Report. Study carried out for the Commission by the Universidad Autonoma de Barcelona, 2007.

http://ec.europa.eu/avpolicy/media_literacy/studies/index_en.htm Accessed on 18 June 2008.

EUROPEAN COMMISSION, Multilingualism. (2009).

http://ec.europe.eu/education/languages-of-europe/index en.htm Accessed on 18 May 2009.

EURYDICE, (2007). National summary sheets on education systems in Europe and ongoing reforms : Portal. Brussels : Directorate-General for Education and Culture. http://eacea.ec.europa.eu/portal/page/portal/Eurydice Accessed on 30 December 2008.

FRANCIS, S. (Ed.) (1971). Libraries in the U.S.S.R. (Translated from the Russian). London : Bingley.

FUCHS, T \& WÖßMANN, L. (2004). What accounts for international differences in student performance?. A re-examination using PISA data. Empirical Economics, Vol. 32, No. 3, pp. 433-64.

http://www.pisa.oecd.org/dataoecd/29/47/33680685.pdf Accessed on 24 November 2008.

GANITSKAYA, I. \& FROLOVA, I. (1978). U.S.S.R. in Library Service to Children : An International Survey

/ edited for the IFLA Section of Children’s Libraries by Colin Ray. Munich [etc.] : K. G. Sauer.

GATES, J. (1968). Introduction to Librarianship. New York : McGraw Hill. 
IFLA/FAIFE (2007). World Report, (2007). Portal. http://www.ifla.org/faife/report/ifla-faife_world_report_2007-reports.htm Accessed on 1 November 2008.

IFLA/UNESCO (1999). School Library Manifesto : The School Library in Teaching and Learning for All. The Hague : IFLANET. http://www.ifla.org/en/publications/iflaunesco-school-library-manifesto-1999 Accessed on 14 May 2009.

IFLA/UNESCO (2002). School Library Guidelines The Hague : IFLANET. http://www.ifla.org/en/publications/the-iflaunesco-school-library-guidelines-2002 Accessed on 14 May 2009.

KENNISNET ICT OP SCHOOL (2006). Four in Balance Monitor 2006 : Evidence on ICT in education. Zoetemeer, The Netherlands : Stichting Kennisnet ICT op School.

LIBECON, (2000). Millennium study. http://www.libecon.org/millenniumstudy Accessed on 28 September 2008.

SCHEERENS, J. (2004). Perspectives on Education Quality, Education Indicators and Benchmarking, European Educational Research Journal, 3(1), pp. 115-138 http://dx.doi.org/10.2304/eerj.2004.3.1.3 Accessed on 19 January 2009.

SINGH, D. (1993). An international comparative study of school libraries. Dissertation in partial fulfilment of the requirements for the degree of Doctor of Philosophy. Tallahassee, Florida : The Florida State University, School of Library and Information Studies.

UNESCO (United Nations Educational, Scientific and Cultural Organisation) (2009). Education for All (EFA) Global Monitoring Report : Overcoming inequality: why governance matters. Paris : UNESCO. http://unesdoc.unesco.org/images/0017/001776/177683E.pdf Accessed on 24 November 2008.

UNESCO (United Nations Educational, Scientific and Cultural Organisation), Institute of Statistics (2006). http://stats.uis.unesco.org/unesco/TableViewer/document.aspx?ReportId=121\&IF_Lan... Accessed on 15 September 2008.

\section{Biographical Notes.}

Helen Boelens is a Ph.D. research student at the Middlesex University, School of Arts and Education, in London. Until December 2008 she was the Chief Librarian at the Kalsbeek College in Woerden, the Netherlands. Boelens is also the Treasurer of the ENSIL Foundation.

\section{Statement of Originality}

This statement certifies that the paper above is based upon original research undertaken by the author and that the paper was conceived and written by the author(s) alone and has not been published elsewhere. All information and ideas from others is referenced. 